\title{
INOVASI TERHADAP PENGAJARAN DAN PEMBELAJARAN BAGI PENERAPAN KEMAHIRAN INSANIAH DALAM MATA KULIAH TAMADUN ISLAM DAN ASIA (TITAS) DI UNIVERSITI MALAYA KUALA LUMPUR MALAYSIA
}

Oleh:

Norazlan Hadi Yaacob ${ }^{1} \&$ Faezah Kassim ${ }^{2}$

Universiti Pendidikan Sultan Idris ${ }^{1} \&$ Universiti Malaya ${ }^{2}$

Email:norazlan@fsk.upsi.edu.my

\begin{abstract}
Abstrak
Penumpuan berlebihan kepada akademik dan suasana pembelajaran yang cenderung mengukur kecemerlangan berdasarkan prestasi dalam peperiksaan didapati tidak memberi kelebihan kepada mahasiswa dalam memperolehi kemahiran insaniah melalui proses pengajaran dan pembelajaran (P\&P) sesuatu mata kuliah. Kajian ini merupakan satu kajian awal dan sebagai permulaan memfokuskan kepada salah satu MPU iaitu TITAS. Ia bertujuan untuk menjelaskan inovasi yang dilaksanakan terhadap kursus TITAS khususnya berkaitan strategi pembelajaran di Universiti Malaya dan melihat persepsi pelajar terhadap inovasi strategi pembelajaran yang menerapkan elemen Kemahiran Insaniah (KI) serta pencapaian mereka di dalam memperolehi KI tersebut. Sebagai satu kajian awal hanya dua elemen KI sahaja yang menjadi fokus iaitu kemahiran kerja berpasukan dan kemahiran berkomunikasi. Metode kajian yang digunakan adalah kajian perpustakaan bagi menjelaskan tentang pelaksanaan kursus TITAS dan menganalisis pencapaian pelajar dalam KI kursus ini. Soal selidik juga diedarkan kepada 120 mahasiswa yang telah mengambil mata kuliah TITAS dan dapatan kajian adalah secara deskriptif iaitu dalam bentuk peratusan dan kekerapan atau frekuensi untuk menganalisis data. Hasil kajian ini mendapati bahawa persepsi mahasiswa terhadap inovasi strategi pembelajaran dan metode penilaian yang dilaksanakan adalah baik. Ini telah memberi kesan yang baik juga kepada pencapaian yang diperoleh dalam penilaian kerja kursus dan pencapaian KI mereka. Mahasiswa tidak menghadapi masalah dalam melaksanakan tugasan secara berkumpulan yang terdiri daripada pelbagai etnik dan latar belakang.
\end{abstract}

Kata Kunci: Mata kuliah Tamadun Islam dan Asia (TITAS), inovasi, strategi pembelajaran, kemahiran insaniah. 


\title{
INNOVATIONS ON TEACHING AND LEARNING IN ENHANCING THE SOFT SKILLS ON THE SUBJECT OF ISLAMIC AND ASIAN CIVILIZATIONS (TITAS) IN THE UNIVERSITY OF MALAYA
}

\begin{abstract}
Excessive focus on academics and learning environments that tend to measure excellence based on the performance in examinations are found to be less beneficial to students in acquiring soft skills through the teaching and learning process (P\&P) of a course. Therefore, innovations have been implemented in the P\&P to ensure that potential students in various soft skills can be further developed through the learning process, and thus improve the quality of the learning outcomes they have acquired. For this purpose, at the University of Malaya, the General Curriculum (MPU) was offered under the management of the International Training and Academic Enrichment Center (CITrA). This research is a preliminary and the first study to focus on one of the MPUs courses which is the TITAS. It aims to explain the innovations implemented on the TITAS particularly related to learning strategies in the University of Malaya and to look at students' perceptions of learning strategy innovations that incorporate the elements of Soft Skills (KI) and their achievements in obtaining such KI. As a preliminary study, only two elements of the KI have been focused which are the teamwork and communication skills. The research method used is a library study to explain the implementation of the TITAS courses and to analyze the students' achievement in this course. The questionnaires are distributed to 120 students who had taken the TITAS course and the findings have been analyzed descriptively in terms of percentage and frequencies. The results of this study showed that students have positive perceptions on innovation in learning strategies and assessment methods implemented. This has also had a positive impact on the achievement of the coursework and their KI achievement. Students' perception of the KI assessment is also positive. Students have no problems to work in group that consist of multicultural and diverse backgrounds. They are less interested in carrying out written reports compared to the assignment than they find to be more enjoyable mainly involving the off-campus activities.
\end{abstract}

Keywords: TITAS Subjects, inovation, strategy in teaching soft skills. 


\section{Pendahuluan}

Di Universiti Malaya, mata pelajaran Pengajian Umum (MPU) diurus di Pusat Latihan Intern dan Pengayaan Akademik (CITrA) iaitu terdiri daripada mata kuliah TITAS, Hubungan Etnik, Asas Pembudayaan Keusahawanan dan Pengenalan kepada Malaysia. Ini bersesuaian dengan salah satu objektif CITrA yang ingin meningkatkan peluang dan platform untuk memupuk sikap kerohanian, ketinggian akhlak dan identitas nasional dengan menawarkan pelbagai kursus yang mempunyai unsur perluasan ilmu (broadbase knowledge), berbilang dan merentas bidang (multidisciplinary and transdisciplinary).

Matlamat CITrA ke arah pendidikan holistik adalah bersandarkan kepada rasional bahawa sistem dunia masa kini yang menyebabkan berlakunya pemampatan jarak dan ruang serta proses kesertamertaan yang digambarkan melalui pergerakan material, manusia dan nilai yang telah melintasi sempadan negara. Fenomena ini mempengaruhi sistem kehidupan termasuk kerohanian, jasmani, pemikiran dan amalan seharian dalam aspek politik, ekonomi, sosial dan pendidikan. Ia turut mempengaruhi makna dan realiti tentang semua aspek kemanusiaan dan fizikal seperti keadilan, kebebasan, hak asasi dan demokrasi. Penerapan nilai dan realiti baharu sama ada positif dan negatif akan mempengaruhi pemikiran, interaksi, tingkahlaku dan moral. Sehubungan dengan tantangan yang perlu dihadapi oleh calon graduan ini, keperluan untuk mempersiapkan mereka dalam pelbagai aspek sama ada mental, fizikal, spiritual dan sebagainya adalah diutamakan bagi membolehkan mereka untuk kekal berdaya saing.

Sehubungan itu, adalah amat perlu bagi pihak universitas untuk menyesuaikan strategi pembelajaran dan kaedah penilaian 
MPU agar mampu mencapai hasil pembelajaran seterusnya matlamat pendidikan negara. Oleh itu, inovasi telah dilakukan terhadap strategi pembelajaran dan metode penilaian yang mana sebelum ini adalah berorientasikan kepada peperiksaan sahaja.

\section{Keperluan Terhadap Inovasi}

Bukan mudah untuk menyediakan sesuatu kurikulum yang relevan dengan keperluan semasa. Perubahan pantas dalam bidang teknologi dan maklumat seringkali menuntut peningkatan ilmu dan kemahiran. Kegagalan institusi pengajian tinggi menyediakan kurikulum yang relevan dengan keperluan semasa dari pihak industri akan menyebabkan graduan yang dikeluarkan tidak mempunyai daya pasaran (Muhamad Rahimi Osman, 2010). Tanggungjawab yang diberikan kepada mata kuliah ini bukan sekadar untuk memberikan ilmu pengetahuan kepada para pelajar tetapi juga perlu diiringi dengan kemahiran hubungan sosial dalam kalangan pelajar yang terdiri daripada pelbagai kaum diterapkan di dalamnya. Interaksi adalah satu elemen penting dalam memantapkan ketamadunan manusia.

Sejarah ketamadunan yang dibina oleh manusia sejak zaman Nabi Adam menyaksikan proses interaksi yang sentiasa berterusan. Interaksi dari sudut pengajian tamadun bermaksud hubungan, pertemuan, komunikasi dan sebagainya antara individu, kelompok, masya-rakat dan seterusnya negara. Secara realitasnya interaksi yang berlaku ialah antara individu dengan masyarakat yang mewakili tamadun tersebut. Interaksi tidak semestinya berlaku kerana tujuan tertentu, malah ia boleh berlaku secara tidak langsung sama ada di peringkat nilai, idea, institusi dan insan (Tamadun Islam dan Tamadun Melayu, 2006; Tamadun Islam dan Tamadun Asia, 2001). 
Bagi memastikan bahawa metode penyampaian menghasilkan pembelajaran yang berkualitas, inovasi terhadap pendekatan pengajaran perlu dilakukan dan membuat perubahan terhadap kaedah yang digunakan. Terdapat beberapa teori yang berkait rapat dengan aktivitas $\mathrm{P} \& \mathrm{P}$ antaranya ialah behaviorisme, kognitivisme dan konstruktivisme. Antara teori yang dinyatakan, teori konstruktivisme sejajar dengan pendekatan pengajaran dan pembelajaran yang berkesan. Teori konstruktivisme berdasarkan andaian bahawa manusia membentuk perspektif tentang dunia mereka sendiri melalui pengalaman masing-masing (Schuman, 1996). Teori ini telah dipelopori oleh Bartlett diikuti oleh Bruner, Ulrick, Neiser, goodman, Kant, Kuhn, Dewey, Habermas dan Piaget (Good \& Brophy, 1990).

Walau apa pun metode penyampaiannya, tenaga pengajar perlu memastikan bahawa setiap sesi pengajaran dan pembelajaran siswa perlu sentiasa aktif dan mengambil bahagian. Pembelajaran tidak semestinya berlaku sewaktu sesi bersemuka antara tenaga pengajar dan siswa sahaja. Bahkan, pembelajaran boleh berlaku di mana-mana sahaja termasuk di luar sesi bersemuka atau ruang kuliah. Oleh itu, tenaga pengajar perlu memberikan ruang dan peluang kepada siswa di luar sesi bersemuka dengan memberi tugasan. Siswa diberi peluang untuk meneroka pembelajaran kendiri. Seseorang tenaga pengajar boleh mempelbagaikan aktivitas termasuk perbincangan, pembentangan, sesi soal jawab, aktivitas refleksi dan sebagainya yang memberi ruang dan peluang kepada siswa untuk meneroka potensi kemahiran insaniah mereka dalam setiap sesi pengajaran dan pembelajaran (Jamaludin Haji Badusah, 2009).

Keseimbangan dalam aspek ilmu pengetahuan dan kemahiran hidup adalah perlu bagi memastikan seseorang 
individu itu berfungsi dengan baik dalam keluarga dan masyarakat (Andreas Totu, 2010). Persoalan mengenai aspek tersebut dan didikan yang seharusnya diberikan bagi membolehkan seseorang itu hidup dengan baik di tempat kerja dan juga di rumah telah dibincang oleh Martin (1994),

... this is now the overriding question: How can we educate both the men and women for carrying out the productive and reproductive processes in society, for living well in both the public world of work and private world of home.

Bagi mencapai keseimbangan tersebut mata kuliah TITAS yang dilaksana telah memasukkan elemen-elemen yang dilihat mampu untuk menghasilkan individu berfungsi seperti mana yang diinginkan. Mata kuliah TITAS telah dilengkapkan dengan elemen kemahiran insaniah iaitu kerja berpasukan (team work) dan kemahiran berkomunikasi. Memandangkan mata kuliah ini wajib diikuti oleh kesemua pelajar, maka kepentingan mata kuliah TITAS sebagai mata kuliah wajib universiti tidak seharusnya dipandang rendah. Syed Hussein Alatas (1998) pernah menyebut tentang kepentingan mata kuliah seperti ini,

It is not a mere distribution of disparate knowledge taken from here and there simply to meet the requirement of a degree. It is selecting attention on definite themes in an analytic and intellectual fashion, not covered by professional disciplines, the goals of which are not to develop a career but to develop the total personality. It is not the intention to teach a little of everything but to teach enough of certain things.

Pandangan ini juga dinyatakan oleh Muhamad Rahimi Osman (2010) bahawa mata kuliah pengajian umum atau mata kuliah wajib universitas tidak boleh dijadikan satu program sampingan, sebaliknya ia perlu dilihat sebagai satu mata kuliah yang perlu dilaksanakan secara serius dan berkesan. Ini adalah kerana 
kursus-kursus ini berkait rapat dengan aspek nilai dan kemanusiaan yang dapat membina jati diri bangsa. Kajian ini dijalankan bagi mencapai beberapa objektif iaitu:

1. Menjelaskan pelaksanaan inovasi terhadap mata kuliah TITAS.

2. Mengenalpasti persepsi mahasiswa dalam inovasi strategi pembelajaran dan KI yang diterapkan.

3. Menganalisis keberkesanan inovasi melalui pencapaian mahasiswa dalam KI kursus.

\section{Metode Penelitian}

Kajian ini dijalankan ke atas 120 orang pelajar Universitas Malaya daripada satu semester sahaja iaitu pada Semester 1 sesi 2018/2019. Riset ini merupakan satu kajian rintis yang mana menurut Polit et. al. (2001; Abd. Majid Konting, 2003), kajian rintis merujuk kepada versi kajian kecil atau percubaan yang dilakukan sebagai persediaan untuk kajian yang lebih besar atau utama. Bagi mencapai objektif pertama dan ketiga, riset perpustakaan digunakan iaitu menjelaskan tentang pelaksanaan kursus TITAS khususnya mengenai kaedah P\&P dan menganalisis pencapaian pelajar dalam KI kursus ini. Bagi objektif kedua, dapatan riset adalah secara deskriptif iaitu dalam bentuk peratusan dan kekerapan atau frekuensi untuk menganalisis data. Responden merupakan pelajar tahun 1 yang mengikuti kursus TITAS di Universiti Malaya. Jumlah keseluruhan mahasiswa yang mendaftar mata kuliah tersebut pada semester 1, sesi 2018/2019 adalah seramai 1420 orang.

Tinjauan persepsi dilakukan bagi mendapatkan gambaran minat, keinginan dan pengetahuan mahasiswa terhadap pelaksanaan strategi pembelajaran kursus TITAS. Diane \& Rolf A Zwaan (t.t) berpegangan kepada teori bahawa proses mental 
manusia disokong oleh persepsi dan tindakan. Dengan kata lain, struktur kognitif manusia berkembang daripada persepsi tindakannya (Zarina Muhammad, 2010). Manakala sikap memainkan peranan penting untuk mencapai kejayaan di dalam sesuatu perkara atau usaha. Sikap dibentuk daripada pengalaman dan persepsi seseorang terhadap sesuatu perkara atau fenomena. Persepsi seseorang itu terhadap sesuatu perkara akan akan membentuk sikap mereka terhadap perkara tersebut. Sikap adalah sesuatu yang mempengaruhi seseorang individu di dalam memberi nilai terhadap simbol objek atau apa yang disukai atau tidak. Seterusnya sikap adalah sesuatu yang terhasil dari perasaan, kepercayaan atau pemikiran seseorang terhadap objek psikologi (Azizi Haji Yahaya, t.t). Ini bermakna, persepsi mahasiswa terhadap mata kuliah TITAS akan membentuk sikap mereka terhadap elemen-elemen KI.

Pada bahagian awal dapat hasil riset akan dihurai mengenai perlaksanaan mata kuliah TITAS sebagaimana yang dinyatakan di dalam objektif pertama riset. Metode yang digunakan adalah metode perpustakaan iaitu kupasan dan huraian berdasarkan kepada Buku Panduan CITrA, dokumen Malaysian Quality Framework (MQF) mata kuliah TITAS dan tulisan mengenai mata kuliah TITAS berdasarkan pengalaman daripada Institut Pengajian Tinggi (IPT) lain dalam melaksanakan mata kuliah ini. Pengumpulan maklumat dilakukan melalui borang soal selidik yang ditadbir sendiri oleh pelajar. Soal selidik dibahagikan kepada tiga bahagian iaitu A. Persepsi mahasiswa terhadap strategi pembelajaran, B. Persepsi mahasiswa terhadap Kerja Berpasukan, C. Dan Persepsi mahasiswa terhadap Kemahiran Berkomunikasi. Manakala pencapaian mahasiswa terhadap KI kerja berpasukan akan dilakukan analisis terhadap kriteria Aplikasi Nilai dalam 
Kerja Kumpulan yang terdapat dalam pemarkahan kerja. Bagi KI kemahiran berkomunikasi dilihat kepada pembentangan. Analisis data yang telah digunakan adalah analisis berbentuk deskriptif. Data-data dihuraikan menggunakan nilai frekuensi atau kekerapan dan peratusan.

\section{Hasil Penelitian}

Pelaksanaan P\&P mata kuliah TITAS di Universiti Malaya sebelum ini menggunakan strategi pembelajaran berasaskan kuliah, kerja lapangan dan pembentangan. Kuliah akan disampaikan oleh dosen dari minggu pertama hingga minggu kesepuluh dan diikuti dengan pembentangan hasil tugasan pada minggu kesebelas hingga keempat belas. Manakala bagi strategi pembelajaran kerja kursus pula terdiri daripada dua bahagian iaitu melalui hasil tugasan kerja kursus dan pembentangan. Kerja kursus ini perlu dilakukan berdasarkan riset lapangan bagi memberi peluang kepada pelajar untuk membuat kajian dan pemerhatian sendiri tentang ilmu ketamadunan di Malaysia. Salah satu tujuan utama mata kuliah TITAS ialah untuk menyumbang kepada pencapaian cita-cita negara untuk mewujudkan perpaduan dan keharmonian dalam kalangan rakyat negara ini (Modul Pengajian Tamadun Islam dan Tamadun Asia, 2009).

Mata kuliah TITAS yang dilaksanakan bermula semester 1 sesi 2015/2016 melakukan beberapa perubahan dari beberapa aspek hasil daripada kajian terdahulu yang memperlihatkan kelemahan dalam mencapai kemahiran insaniah tertentu. Kemahiran insaniah yang diterapkan adalah kemahiran berkomunikasi, kerja berpasukan dan etika dan moral profesional. Penambahan elemen etika dan moral profesional dalam kursus ini adalah bersesuaian dengan matlamatnya yang menerapkan nilai- 
nilai dan persefahaman antara pelbagai budaya melalui kaedah pembelajaran kuliah, lawatan sambil belajar, kerja kursus, dialog dan pembentangan (Pemetaan: Kursus - Kemahiran Insaniah, Dokumen MQF).

Hasil Pembelajaran mata kuliah yang ketiga iaitu "Menunjukkan kebolehan berinteraksi dan berdialog peradaban sesama serta berlainan budaya" amat menekankan kepada kepentingan para pelajar untuk memperolehi elemen kemahiran insaniah dari segi berkomunikasi dan kerja berpasukan (Penyelarasan Hasil Pembelajaran Kursus-Program, Strategi Pembelajaran dan Kaedah Penilaian, Dokumen MQF).

Mahasiswa diharapkan agar berkebolehan dalam perundingan dan berupaya mencapai persetujuan. Mereka seharusnya berupaya untuk memahami pandangan dan pendapat rakan perbincangan untuk menerima atau menolak sebarang keputusan kumpulan. Tiga elemen kemahiran berkomunikasi yang perlu dikuasai oleh pelajar terdiri daripada CS1, CS2 dan CS3. CS1 ialah kebolehan menyampaikan idea dengan terang, berkesan dan dengan penuh keyakinan, secara lisan dan bertulis. CS2 ialah kebolehan mengamalkan kemahiran mendengar yang aktif dan memberikan maklum balas. Serta kebolehan CS3 iaitu kebolehan untuk membuat pembentangan yang terang dengan penuh yakin bersesuaian dengan tahap pendengar. Kesemua ini adalah elemen kemahiran insaniah yang diterapkan di dalam mata kuliah TITAS di Universiti Malaya (Panduan Taksonomi Pengajaran dan Pembelajaran \& Elemen Kemahiran Insaniah, 2010; ).

Kemahiran kerja berpasukan (TS) melibatkan kebolehan untuk bekerjasama dengan orang lain daripada pelbagai latar belakang sosiobudaya untuk mencapai matlamat yang sama. Kerja berpasukan bermaksud kerja yang dilaksanakan oleh individu 
yang mempunyai ciri yang berbeza yang bekerja dalam satu kumpulan yang mempunyai matlamat yang sama untuk menyiapkan sesuatu tugasan. Terdapat lima elemen kamhiran insaniah kerja berpasukan menurut modul kemahiran insaniah. Tiga daripadanya ialah kemahiran insaniah mesti iaitu TS1, TS2 dan TS3. TS1 ialah kebolehan untuk membinca hubungan yang baik, berinteraksi dengan orang lain dan bekerja secara efektif bersama mereka untuk mencapai objektif yang sama. TS2 ialah kebolehan untuk memahami dan mengambil peranan bersilih ganti antara ketua kumpulan dan ahli kumpulan dan TS3 ialah kebolehan untuk mengenal dan menghormati sikap, kelakuan dan kepercayaan orang lain (Jamaludin Haji Badusah, 2009; Panduan Taksonomi Pengajaran dan Pembelajaran \& Elemen Kemahiran Insaniah, 2010; MQF 2nd Edition, 2017).

Pada sesi 2018/2019 strategi pembelajaran yang dilaksanakan adalah pelbagai dan memantapkan lagi dari segi penerapan dan penilaian kemahiran insaniah tersebut. Strategi pembelajaran yang dimaksudkan adalah lawatan ilmiah, kerja kursus dan pembentangan. Kaedah penilaiannya adalah melalui ulasan lawatan ilmiah, sesi dialog, hasil kerja kursus dan pembentangan (Penyelarasan Hasil Pembelajaran Kursus-Program, Strategi Pembelajaran dan Kaedah Penilaian, Dokumen MQF).

Berdasarkan kepada Hasil Pembelajaran Kursus yang kedua iaitu "Mengaplikasikan nilai-nilai murni yang dikongsi bersama bagi memantapkan sahsiah, semangat persefahaman dan saling menghormati antara pelbagai tamadun dan agama”, jelaslah bahawa elemen etika dan moral profesional amat perlu menjadi kemahiran insaniah yang diterapkan di dalam kursus ini. Elemen ini akan dinilai melalui strategi pembelajaran lawatan ilmiah, kerja kursus dan pembentangan. Manakala empat metode penilaian 
digunakan iaitu ulasan lawatan ilmiah, sesi dialog, kerja kursus dan pembentangan (Penyelarasan Hasil Pembelajaran Kursus Program, Strategi Pembelajaran dan Kaedah Penilaian, Dokumen MQF).

Setiap daripada tugasan yang diberikan adalah secara berkumpulan. Bagi memperolehi hasil tugasan yang baik, elemen kerja berpasukan dan kemahiran berkomunikasi adalah amat perlu ditekankan oleh mahasiswa sepanjang proses menyiapkan tugasan. Kerja berkumpulan adalah asas kepada membina kemahiran kerja berpasukan. Bagi membolehkan mahasiswa memperolehi kemahiran tersebut kerja kursus atau tugasan perlu dilakukan secara berkumpulan yang mana setiap kumpulan mesti terdiri daripada pelbagai etnik.

Selain itu, mahasiswa juga akan dinilai semasa pembentangan. Mahasiswa yang mendengar perlu memberi perhatian dan mengenengahkan soalan atau kemusykilan kepada kumpulan yang membentang. Keberkesanan interaksi akan dilihat dari segi cara melontarkan soalan dan menjawab dengan berhemah. Mahasiswa perlu belajar mengawal suasana untuk mengelakkan sebarang ketegangan yang mungkin berlaku semasa berlangsungnya sesi ini. Melalui pengalaman ini pelajar akan dapat belajar bertolak ansur dan memilih cara berkomunikasi yang lebih baik bagi membentuk interaksi yang harmoni.

Di dalam strategi pembelajaran ini juga telah ditambah lawatan ilmiah. Lawatan ini adalah berdasarkan kepada pemahaman budaya, agama kaum yang pelbagai dan isu-isu semasa di Malaysia. Lawatan ini akan dilakukan di tempat-tempat ibadah, pusat kebudayaan, badan kebajikan, agensi yang menangani isu sosial dan sebagainya. Matlamat utama aktivitas ini dilakukan adalah untuk memberi pendedahan dan pengalaman 
kepada mahasiswa. Semasa lawatan tersebut sesi dialog akan diadakan dengan pihak yang mengendalikan tempat lawatan tersebut bagi membolehkan pemahaman yang lebih mendalam mengenai satu-satu perkara yang selama ini hanya bersifat persepsi sahaja.

Seharusnya di akhir proses pengajaran dan pembelajaran ini, elemen moral dan etika profesional yang merupakan elemen kemahiran insaniah yang baru diterapkan ini akan diperolehi mahasiswa. Secara makro, aspek moral dijadikan panduan untuk menjadikan seorang itu insan yang bermoral tetapi secara mikro, seseorang hanya dianggap bermoral apabila pemikiran, emosi dan tingkah lakunya konsisten dalam melakukan perkara-perkara yang diterima dalam masyarakat Malaysia (Vishalache Balakrishnan, 2009). Sehubungan itu, ia berkait dengan etika. Etika merupakan sebahagian daripada cara manusia berurusan dalam kehidupan seharian, maka ia sangat penting kepada individu, keluarga, organisasi dan masyarakat. Bahkan dilihat dalam konteks sejagat, ia sangat penting kepada manusia seluruhnya (Ibrahim Mamat, 2000).

Kementerian Pengajian Tinggi telah menggariskan bahawa para pelajar seharusnya mempunyai etika dan prinsip yang jelas terhadap sebarang tindakan mereka. Tingkah laku mereka seharusnya selari dengan etika dan budaya masyarakat. Mahasiswa juga harus mampu membuat keputusan yang tidak mementingkan diri sendiri dan anggota keluarga apabila memberikan pertimbangan dalam masyarakat (Jamaludin Haji Badusah, 2009). Oleh itu, dengan strategi pembelajaran yang pelbagai dari segi aktivitas dan melibatkan tugasan berkumpulan akan membolehkan para mahasiswa melalui sendiri pengalaman berinteraksi dengan ahli-ahli kumpulan yang terdiri daripada 
pelbagai kaum. Lawatan ilmiah yang dilakukan juga akan memantapkan lagi pemahaman tentang budaya dan tamadun lain serta ini memberi kesan kepada tingkah laku mereka apabila berada di dalam situasi yang berbeza daripada budaya asal.

Riset ini juga bertujuan untuk mengenalpasti persepsi mahasiswa terhadap pelaksanaan strategi pembelajaran dan kaedah penilaian yang digunakan dan KI yang ingin diterapkan. Strategi pembelajaran yang menjadi fokus adalah lawatan ilmiah, kerja kursus dan pembentangan. Sebagai satu kajian awal hanya dua elemen KI yang menjadi fokus iaitu kemahiran kerja berpasukan dan kemahiran berkomunikasi. Seterusnya, pencapaian mahasiswa dalam memperolehi KI ini akan dianalisis untuk melihat keberkesanan strategi pembelajaran yang digunakan di dalam kursus ini.

Jadual 1: Persepsi Mahasiswa Terhadap Strategi Pembelajaran (Kaedah Penilaian)

\begin{tabular}{|c|c|c|c|c|c|c|c|c|c|c|c|}
\hline \multirow{2}{*}{ Bil. } & \multirow{2}{*}{ Item } & \multicolumn{2}{|c|}{ STS } & \multicolumn{2}{|c|}{ TS } & \multicolumn{2}{|c|}{ AS } & \multicolumn{2}{|c|}{$\mathbf{S}$} & \multicolumn{2}{|c|}{ SS } \\
\hline & & $\mathbf{f}$ & $\%$ & $\mathbf{f}$ & $\%$ & $\mathbf{f}$ & $\%$ & $\mathbf{f}$ & $\%$ & $\mathbf{f}$ & $\%$ \\
\hline 1. & $\begin{array}{l}\text { Lawatan } \\
\text { Ilmiah }\end{array}$ & 5 & 4.1 & 10 & 8.3 & 12 & 10.0 & 68 & 56.6 & 25 & 20.8 \\
\hline 2. & Tugasan & 20 & 16.6 & 15 & 12.5 & 15 & 12.5 & 60 & 50.0 & 20 & 16.6 \\
\hline 3. & Pembentangan & 5 & 4.1 & 10 & 8.3 & 8 & 6.6 & 65 & 54.1 & 32 & 26.6 \\
\hline
\end{tabular}

Berdasarkan jadual 1, dapat dilihat bahawa sebahagian besar mahasiswa bersetuju dengan kerja kursus yang perlu dilaksanakan oleh mereka. Bagi aktivitas lawatan ilmiah, seramai 68 (56 peratus) mahaiswa tidak menghadapi masalah untuk melaksanakan kerja kursus tersebut. Manakala, 25 (20.8 peratus) mahasiswa lagi sangat setuju dengan aktiviti lawatan ilmiah. Walau bagaimanapun, 12 (10 peratus) mahasiswa lagi agak setuju dengan lawatan ilmiah ini, diikuti seramai 15 (12.5 peratus) mahasiswa tidak bersetuju dengannya dan seramai 5 (4.1 peratus) 
mahasiswa amat tidak bersetuju dengan pelaksanaan lawatan ilmiah. Bagi kerja kursus lain iaitu tugasan, seramai 60 (50 peratus) mahaiswa setuju dan 20 (16.6 peratus) mahasiswa amat setuju dengan tugasan ini.

Pembentangan pula menunjukkan seramai $65 \quad$ (54.1 peratus) mahasiswa setuju dan 32 (26.6 peratus) mahasiswa amat setuju dengan tugasan tersebut. Keadaan ini disebabkan oleh penglibatan mahasiswa di dalam aktivitas di luar kelas dan mereka menghasilkan laporan berbentuk video. Aktivitas seperti ini memang digemari oleh mahasiswa yang mana mereka perlu berkunjung ke tempat-tempat yang menarik dan baharu.

Setiap aspek KI yang dinilai dalam pelaksanaan kerja kursus juga perlu dilihat bagi memastikan keberkesanan kesepaduan atau penerapan KI. Di dalam jadual 2, bagi KI kerja berpasukan disebut sebagai aplikasi nilai dalam kerja kumpulan dan telah dibahagikan kepada tiga kriteria iaitu mengikut CS1, CS2 dan CS3.

Jadual 2 : Persepsi Mahasiswa terhadap KI Kerja Berpasukan

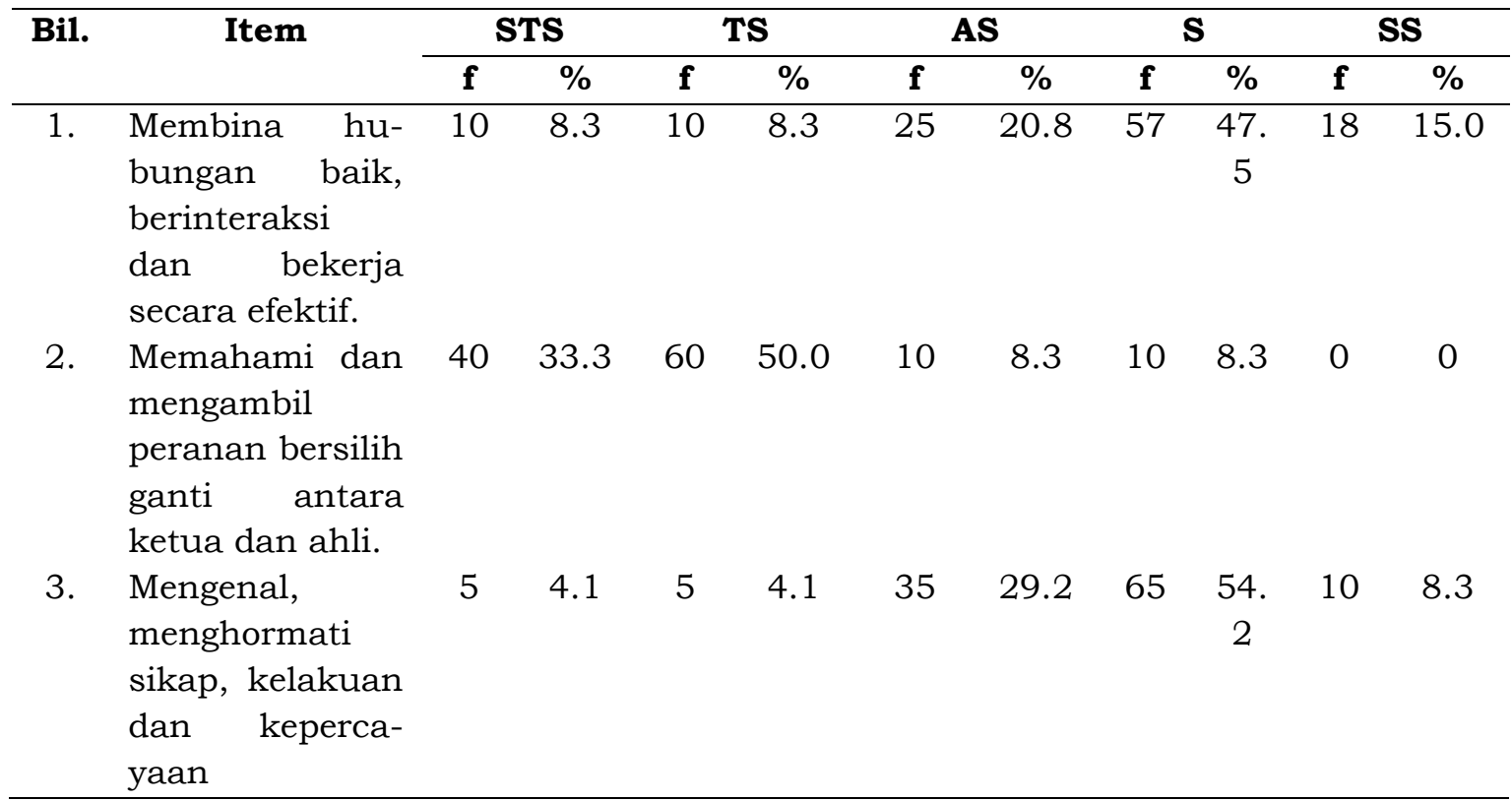


Jadual 2 menunjukkan bahawa kriteria mengenal, menghormati sikap, kelakuan dan kepercayaan orang lain adalah perkara yang paling tinggi berlaku dan dipersetujui oleh mahasiswa sebagai aspek penilaian dalam kerja berpasukan. Seramai 65 (54.2 peratus) mahasiswa bersetuju, 10 (8.3 peratus) mahasiswa amat bersetuju dan 35 (29.2 peratus) mahasiswa agak setuju bahawa aspek tersebut berlaku dan dilaksanakan dalam kumpulan mereka. Bagi membina hubungan baik, berinteraksi, bekerja secara efektif menunjukkan seramai 57 (47.5 peratus) mahasiswa bersetuju, 10 (15 peratus) mahasiswa sangat bersetuju dan 25 (20.8 peratus) mahasiswa agak bersetuju terhadap kriteria ini untuk dinilai dan mereka telah melaksanakannya di dalam kerja berkumpulan.

Namun begitu, bagi aspek memahami dan mengambil peranan bersilih ganti antara ketua dan ahli didapati tidak dipersetujui oleh sebahagian besar mahasiswa. Seramai 60 (50 peratus) mahasiswa tidak bersetuju dan 40 (33.3 peratus) mahasiswa sangat tidak setuju serta tidak melaksanakan atau berlaku di dalam kerja berpasukan. Pelaksanaan kerja kursus telah mendorong mahasiswa untuk berinteraksi dengan ahli kumpulan dengan lebih berkesan sepanjang proses menghasilkan tugasan.

Mereka dapat bertingkahlaku saling menghormati, bertolak ansur dan bekerjasama dengan ahli kumpulan walaupun terdiri daripada rakan-rakan yang berbeza latar belakang. Berikutnya adalah dapatan kajian mengenai persepsi mahasiswa terhadap KI kemahiran berkomunikasi. Berdasarkan jadual 3, ketiga-tiga kriteria yang dinilai menunjukkan keputusan yang hampir sama diberikan oleh mahasiswa. 
Jadual 3 : Persepsi Mahasiswa terhadap KI Kemahiran Berkomunikasi

\begin{tabular}{|c|c|c|c|c|c|c|c|c|c|c|c|}
\hline \multirow{2}{*}{ Bil. } & \multirow{2}{*}{ Item } & \multicolumn{2}{|c|}{ STS } & \multicolumn{2}{|c|}{ TS } & \multicolumn{2}{|c|}{ AS } & \multicolumn{2}{|c|}{$\mathbf{S}$} & \multicolumn{2}{|c|}{ SS } \\
\hline & & f & $\%$ & $\mathbf{f}$ & $\%$ & $\mathbf{f}$ & $\%$ & $\mathbf{f}$ & $\%$ & f & $\%$ \\
\hline 1. & $\begin{array}{l}\text { Menyampaikan } \\
\text { idea dengan } \\
\text { terang, berkesan } \\
\text { dan dengan } \\
\text { penuh keyakinan } \\
\text { secara lisan dan } \\
\text { bertulis. }\end{array}$ & 2 & 1.6 & 10 & 8.3 & 22 & 18.3 & 66 & 55.0 & 20 & 16.6 \\
\hline 2. & $\begin{array}{l}\text { Mendengar } \\
\text { dengan aktif dan } \\
\text { memberi } \\
\text { maklum balas. }\end{array}$ & 2 & 1.6 & 10 & 8.3 & 20 & 16.6 & 68 & 56.6 & 20 & 16.6 \\
\hline 3. & $\begin{array}{l}\text { Pembentangan } \\
\text { yang terang, } \\
\text { penuh yakin } \\
\text { bersesuaian } \\
\text { dengan tahap } \\
\text { pendengar. }\end{array}$ & 2 & 1.6 & 10 & 8.3 & 20 & 16.6 & 66 & 55.0 & 22 & 18.3 \\
\hline
\end{tabular}

Kebolehan mendengar dengan aktif dan memberi maklum balas adalah yang paling tinggi mendapat respon daripada mahasiswa dari segi pelaksanaannya iaitu seramai 68 (56.6 peratus) mahasiswa yang bersetuju, 20 (16.6 peratus) mahasiswa sangat setuju. Bagi kebolehan menyampaikan idea dengan terang, berkesan dan dengan penuh keyakinan secara lisan dan bertulis seramai 66 (55 peratus) yang bersetuju dan 20 (16.6 peratus) agak setuju dengan aspek ini sebagai elemen yang dinilai dan telah dilaksanakan semasa pembentangan.

Begitu juga dengan kebolehan membentang dengan terang, penuh yakin bersesesuaian dengan tahap pendengar yang menunjukkan seramai 66 (55 peratus) mahasiswa, seramai 22 (18.3 peratus) mahasiswa lagi sangat bersetuju dan 20 (16.6 peratus) mahasiswa agak setuju dengan elemen ini untuk dinilai serta telah dilaksanakan oleh mereka. Kerjasama yang tinggi ditunjukkan oleh mahasiswa semasa membentangkan hasil kerja 
kursus mereka. Pencapaian mahasiswa dilihat berdasarkan kepada hasil analisis pencapaian KI yang diperoleh daripada kaedah penilaian kerja kursus yang telah dilaksanakan.

Jadual 4: Pencapaian Pelajar dalam Kemahiran Insaniah

\begin{tabular}{llrc}
\hline Bil. & \multicolumn{1}{c}{ Item } & f & \% \\
\hline 1. & Kemahiran Kerja Berpasukan & 120 & 100 \\
2. & Kemahiran Berkomunikasi & 120 & 100 \\
\hline
\end{tabular}

Berdasarkan Jadual 4, keseluruhan mahasiswa iaitu 120 orang atau $100 \%$ mencapai KI kerja berpasukan yang telah ditetapkan. Begitu juga dengan KI kemahiran berkomunikasi menunjukkan kesemua mahasiswa mencapai kriteria yang telah ditetapkan dalam penilaian yang mana ia adalah berdasarkan kepada pembentangan kerja kursus yang dilaksanakan oleh para mahasiswa tersebut. Memandangkan persepsi mahasiswa terhadap strategi pembelajaran dan metode penilaian yang baik, ini telah memberi kesan yang baik juga kepada pencapaian yang diperoleh dalam penilaian kerja kursus dan pencapaian KI mereka. Didapati bahawa metode tidak menghadapi masalah dalam melaksanakan tugasan secara berkumpulan yang terdiri daripada pelbagai etnik dan latar belakang. Mereka juga kurang berminat untuk melaksanakan tugasan berbentuk laporan bertulis berbanding tugasan yang dilihat lebih menyeronokkan seperti lawatan ilmiah dan menghasilkan video. Oleh itu, seharusnya strategi pembelajaran dan kaedah penilaian perlu dipelbagaikan oleh pelaksana mata kuliah TITAS bagi memastikan ia kekal relevan dan mantap sebagai medium dalam menyampaikan hasrat matlamat pelaksanaan kursus ini di institut pengajian tinggi di Malaysia. 


\section{Simpulan}

Inovasi terhadap P\&P dan pelaksanaan mata kuliah TITAS di Universitas Malaya adalah untuk membantu menerapkan kemahiran insaniah tertentu. Inovasi ini bertujuan untuk meningkatkan dan memantapkan kebolehan berinteraksi dalam kalangan mahasiswa khususnya dari segi kemahiran kerja berkumpulan, berkomunikasi dan penguasaan terhadap elemen moral dan etika profesional. Namun, sebagai riset awal hanya dua elemen KI yang dinilai iaitu iaitu kemahiran kerja berpasukan dan kemahiran berkomunikasi. Melalui P\&P yang lebih jelas hala tuju dan mantap strategi pembelajarannya, mata kuliah ini akan lebih berjaya menerapkan elemen KI dan sekaligus memupuk kesedaran dalam kalangan mahasiswa mengenai nilai-nilai sejagat serta menyatukan mahasiswa yang terdiri daripada latar belakang budaya yang berbeda. Kesedaran yang mendalam mengenai nilainilai sejagat membantu memupuk kesefahaman dalam sesebuah masyarakat. Kesedaran ini mempunyai nilai pendidikan yang tinggi dalam membentuk kesejahteraan dalam kalangan masyarakat Malaysia yang berbilang kaum, agama, bahasa, dan budaya.

\section{Daftar Pustaka}

Abd. Aziz Abd. Talib. (2000). Pedagogi Bahasa Melayu: Prinsip, Kaedah dan Teknik. Kuala Lumpur: Utusan Publications \& Distributors Sdn. Bhd.

Abdul Latif Samian dan Mohamad Sabri Haron. (2000). Pengajian Umum di Alaf Baru. Dalam Wan Kamal Mujani (eds.). Tamadun Islam DalamPendidikan Liberal: Pendekatan Yang Sewajarnya Pada Alaf Baru. Cet. 1. Bangi: Pusat Pengajian Umum UKM. 
Andreas Totu (2010). Pusat Penataran Ilmu dan Bahasa: Pengalaman dan Cabaran. Dalam MALIM - Jurnal Pengajian Umum Asia Tenggara. Vol. 11. Bangi: Pusat Pengajian Umum, UKM.

Good, T. L. \& Brophy, J. E. (1990). Educational Psychology: a realistic approach. White Plains: Longman.

Hashim Hj. Musa. (2005). Ke Arah Pengajaran TITAS dan Hubungan Etnik Yang Holistik. Dalam Prosiding Seminar Pemantapan Kurikulum TITAS dan Hubungan Etnik Peringkat Kebangsaan 2005. Diselenggara oleh Unit TITAS, Pusat Pemikiran Dan Kefahaman Islam (CITU) UiTM. Pusat Penerbitan Universiti (UPENA): UiTM Shah Alam.

Ibrahim Mamat (2000). Etika untuk Mahasiswa. Kuala Lumpur: Kumpulan Budiman Sdn. Bhd.

Jamaludin Haji Badusah, Rosna Awang Hashim, Mohd. Majid Konting, Turiman Suani, Maria Salih \& Norhafezah Yusof. Pembangunan Pelajar: Memperkasakan Kokurikulum Institusi Pengajian Tinggi. 2009. Serdang: Penerbit Universiti Putra Malaysia.

Malaysian Qualification Framework (MQF) 2nd Edition. 2017. Malaysian Qualification Agency (MQA).

Martin, J.R. (1994). Changing the Educational Landscape: Philosophy, Women and Curriculum. New York: Routledge.

Mok Soon Sang. (2010). Pedagogi Untuk Pengajaran-Pembelajaran. Puchong. Penerbitan Multimedia.

Muhamad Rahimi Osman. (2010). Peranan Kursus Pengajian Umum dalam Pembangunan Kemahiran Insaniah: Pengalaman UiTM. Dalam MALIM - Jurnal Pengajian Umum Asia Tenggara. Vol. 11. Bangi: Pusat Pengajian Umum, UKM.

Osman Abu Bakar, Azizan Baharuddin \& Zaid Ahmad (eds.) (2009). Modul Pengajian Tamadun Islam dan Tamadun Asia. Kuala Lumpur: Penerbit Universiti Malaya.

Schuman, L. (1996). Perspectives on Instruction. Diperoleh dari http://edweb.sd.su.edu/courses/edtec540?perspectives/pers pective.html. pada 22 Ogos 2009. Dipetik daripada Jamaludin 
Haji Badusah, Rosna Awang Hashim, Mohd. Majid Konting, Turiman Suani, Maria Salih \& Norhafezah Yusof. Pembangunan Pelajar: Memperkasakan Kokurikulum Institusi Pengajian Tinggi. 2009. Serdang: Penerbit Universiti Putra Malaysia.

Syed Hussein Alatas. (1998). Philosophical Foundation of General Education. Dalam Abdul Kadir $\mathrm{Hj}$ Din dan Mus Chairil Samani (eds.). General Studies: The Eduvation of Man. Bangi: Pusat Pengajian Umum, UKM.

Ting Chew Peh. (1987). Hubungan Ras dan Etnik: Suatu Pengantar. Kuala Lumpur: Pustaka Dimensi.

Vishalache Balakrishnan (2009), Pendidikan Moral Untuk Universiti dan Kolej, Shah Alam: Arah Pendidikan Sdn. Bhd.

----------. (2006). Tamadun Islam dan Tamadun Melayu. Kuala Lumpur: Penerbit Universiti Malaya.

----------. (2001). Tamadun Islam dan Tamadun Asia. Kuala Lumpur: Penerbit Universiti Malaya.

Dokumen MQF dan CITrA, Universiti Malaya.

Panduan Taksonomi Pengajaran dan Pembelajaran \& Elemen Kemahiran Insaniah. (2010). Kuala Lumpur: Universiti Malaya.

Pemetaan: Kursus - Kemahiran Insaniah. (t.t). Universiti Malaya.

Penyelarasan Hasil Pembelajaran Kursus - Program, Strategi Pembelajaran dan Kaedah Penilaian. (t. t). Universiti Malaya.

Proforma Kursus GIG1001 TITAS, (t.t). Universiti Malaya. 